REPORTS OF MORPHOLOGY
Official Journal of the Scientific Society of Anatomists,
Histologists, Embryologists and Topographic Anatomists
of Ukraine
journal homepage: https://morphology-journal.com

\title{
Submicroscopic changes of alveoli of respiratory department of lungs a day after experimental thermal trauma
}

\author{
Nebesna Z.M. ${ }^{1}$, Bashynska O.I. ${ }^{2}$, Ocheretna N.P. ${ }^{2}$, Galunko G.M. ${ }^{2}$, Slyvka O. Ya. ${ }^{2}$ \\ ${ }^{1}$ Ivan Horbachevsky Ternopil National Medical University of the Ministry of Health of Ukraine, Ternopil, Ukraine \\ ${ }^{2}$ National Pirogov Memorial Medical University, Vinnytsya, Ukraine
}

\section{ARTICLE INFO}

Received: 15 June, 2019

Accepted: 20 July, 2019

UDC: $618.173-039.11-053.7 / .84$

\section{CORRESPONDING AUTHOR}

e-mail: nebesna_zm@tdmu.edu.ua Nebesna Z.M.

\begin{abstract}
Deep, large thermal burns are not limited to local lesions of tissues, they cause significant disruption of all systems and organs of the organism, change in metabolic processes. It is revealed that the primary links in the pathogenesis of burn disease are destruction of the skin, impaired neuroendocrine regulation and significant hemodynamic disorders. The reorganization of structures and impaired lung function, in response to a pathological process in the body, is attracting increasing attention of scientists. The aim of the study was to establish a submicroscopic rearrangement of the alveoli after a thermal lesion for 1 day after the experimental thermal trauma. Grade III burns were applied under ketamine anesthesia with copper plates heated in boiled water to a temperature of $97-100^{\circ} \mathrm{C}$. The size of the lesion area was $18-20 \%$ of the epilated surface of the body of rats. An experimental study of the structural components of lung alveoli after burn injury was performed on laboratory white male rats weighing 160-180 g. Euthanasia of rats was performed after ketamine anesthesia by decapitation. In the experiment, the study of the submicroscopic state of the walls of the alveoli of the lungs after thermal trauma was done. It is established that in the stage of shock after the application of burn injury - 1 day, in the alveoli of the respiratory department of the lung, there are adaptive compensatory and initial destructive changes of all structural components of the alveoli. Damage to the ultrastructure of the aerohematical barrier is manifested by intracellular edema and edema of the organelles of the endothelial cells, respiratory and secretory epitheliocytes, and the amount of heterochromatin increases in their deformed nuclei. The basement membrane also has signs of edema, sometimes homogeneous, fuzzy. The decrease in the number of vesicles and micropinocytotic vesicles in endothelial and respiratory epitheliocytes leads to impaired endothelial and alveolar metabolism. Numerous actively phagocytic alveolar macrophages with a wellexpressed lysosomal apparatus are found in the alveoli. Initial alternative alterations of the ultrastructure of the components of the air-barrier barrier lead to disruption of gas exchange in the respiratory department of the lungs

Keywords: lung alveoli, aerohematic barrier, submicroscopic changes, thermal trauma.
\end{abstract}

\section{Introduction}

Burns are the most common type of injury and are accompanied by significant changes in the structure and function of organs and systems of the affected organism $[1,3,4,5,9,11,16]$. In the early term after the injury disturbance of the enzyme homeostasis is caused by the disintegration of tissues in the lesion area, the subsequent destruction of the internal organs $[10,12,18]$. The disorders are directly related to changes in the burned skin as a source of biologically active substances that enter the bloodstream. Other sources of biologically active substances are organs and tissues that are not directly exposed to thermal effects, but are in a state of ischemia and circulatory hypoxia $[3,8,13]$. In the area of the lesion, after a thermal injury, a significant inflammatory reaction occurs, which is accompanied by the formation of biologically active substances, tissue breakdown products, specific and nonspecific toxins, which is the trigger mechanism of burn intoxication [8, 13, 15].

In the affected organism occurs centralization of circulation, which is adaptive in nature, but at the same time leads to significant disorders of regional and peripheral circulation. Not compensated disorders of microcirculation, 
which accrue in time, lead to disorders of the systemic circulation and impaired function of all organs and systems $[3,7]$. Hypovolemia is one of the leading factors leading to impaired lung respiratory function $[14,17,19]$. In a small circle of circulation the peripheral vascular resistance increases congestion develops. The decrease in circulating blood volume occurs mainly due to plasma loss [2]. Due to the loss of skin barrier function, as well as increased vascular permeability due to the action of vasoactive substances (histamine, serotonin, bradykinin, etc.), there is a pronounced plasma loss.

Given that the components of the respiratory department of the lungs after thermal trauma are not fully understood, it is advisable to conduct an in-depth study of the submicroscopic state of the cells of the alveoli wall of the respiratory department of the lungs.

Therefore, the purpose of the work was to establish a submicroscopic rearrangement of alveoli of the lungs of animals after thermal lesion in the shock stage after the experimental burn injury.

\section{Materials and methods}

The experiments were performed on 15 adult white male rats. The animals were kept on the standard diet of the vivarium of Ivan Horbachevsky Ternopil National Medical University of the Ministry of Health of Ukraine. Animal care and all manipulations were carried out in accordance with the provisions of the "European Convention for the Protection of Vertebrate Animals Used for Experiments and for Other Scientific Purposes" (Strasbourg, 1986) and in accordance with the provisions of the "General Ethical Principles for Experiments on animals", approved by the First National Congress on Bioethics (Kyiv, 2001). Grade III burns were applied under ketamine anesthesia with copper plates heated in boiled water to a temperature of $97-100^{\circ} \mathrm{C}$. The size of the lesion area was $18-20 \%$ of the epilated surface of the body of rats. On a daily examination, we monitored their general condition, the extent of local changes in the area of the burn wound, body weight, and mortality. The object of the study was the lungs. To study submicroscopic changes, animals were decapitated under ketamine anesthesia for 1 day, which, according to modern concepts, corresponds to the stage of shock of burn disease [13].

For ultrastructural studies, lung pieces were collected, fixed in $2.5 \%$ glutaraldehyde solution, postfixed with $1 \%$ osmium tetroxide solution on phosphate buffer. Further processing was carried out according to conventional methods [5]. Ultra-thin sections made on an LKB-3 ultramicrotome were counterstained with uranyl acetate, lead citrate according to the Reynolds method, and studied in an electron microscope PEM-125K.

\section{Results}

Electron microscopic studies have shown that the stage of shock for hemocapillaries is characterized by reactive

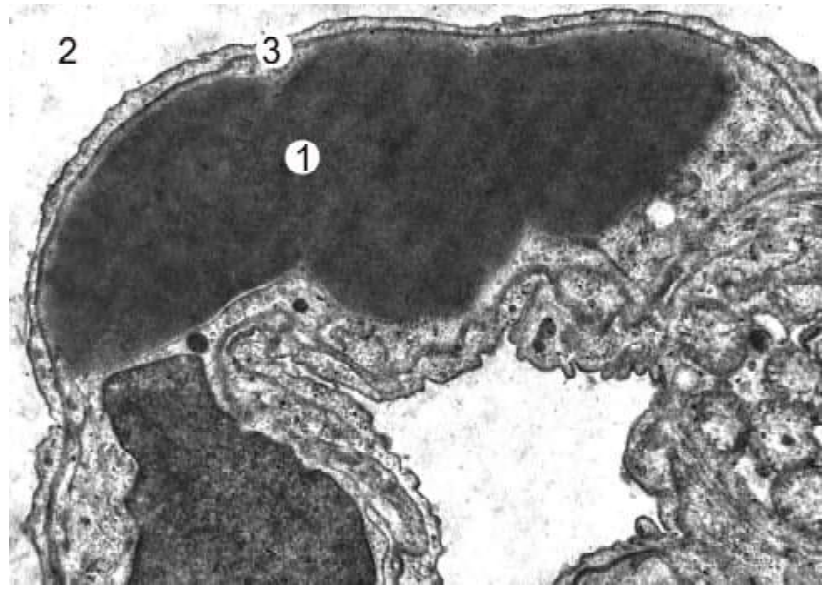

Fig. 1. Submicroscopic condition of the hemocapillary of the respiratory department of the lung animal a day after thermal trauma. Hemopapillary lumen (1), alveoli lumen (2), aerohematic barrier (3). x12000.

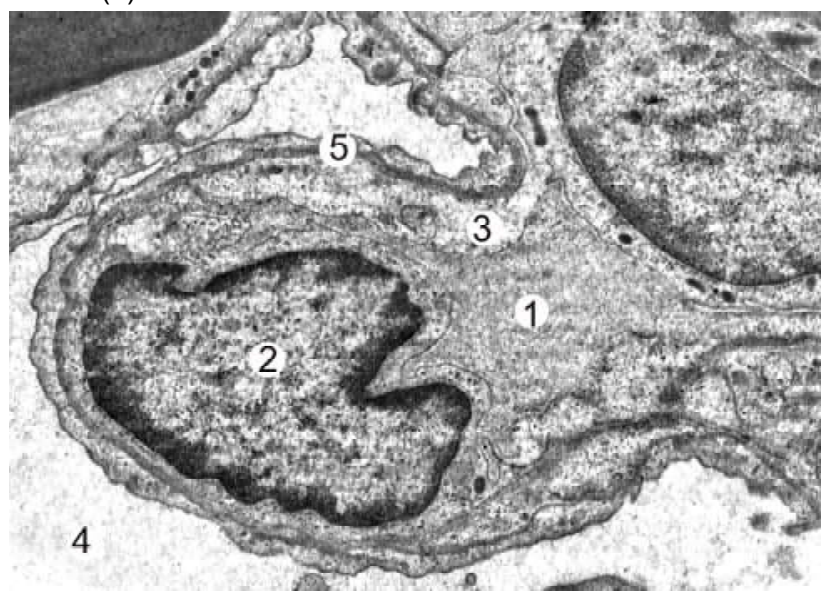

Fig. 2. The ultrastructural state of the hemocapillary of the respiratory compartment of the animal lung a day after thermal trauma. Hemocapillary lumen (1), endothelial cell nucleus (2), endothelial cell cytoplasm swollen (3), alveoli lumen (4), aerohematic barrier (5). x11000.

changes, which are manifested by the enlargement of the lumen, significant blood filling and stasis formation. In endothelial cells, the initial signs of the destructive changes that are manifested by the disruption of the nucleus and cytoplasmic organelles are established. The hypertrophied nuclei have a rounded shape, with some of the invasions of karyolemma and the indistinct outlines of its membranes. Perinuclear space in some areas is expanded. The karyoplasm contains mainly euchromatin, however, in the part of the nuclei, marginally located tubercles of heterochromatin are noted. Enlarged tubules of the endoplasmic reticulum are located in the perinucleus zone, and the Golgi complex is represented by thickened cisterns and large vesicles. Peripheral, cytoplasmic areas of the endothelial cells were characterized by enlightenment and focal edema and a decrease in the number of pinocytosis vesicle and caveolae (Fig. 1).

The nuclei of the respiratory alveolocytes have a rounded 


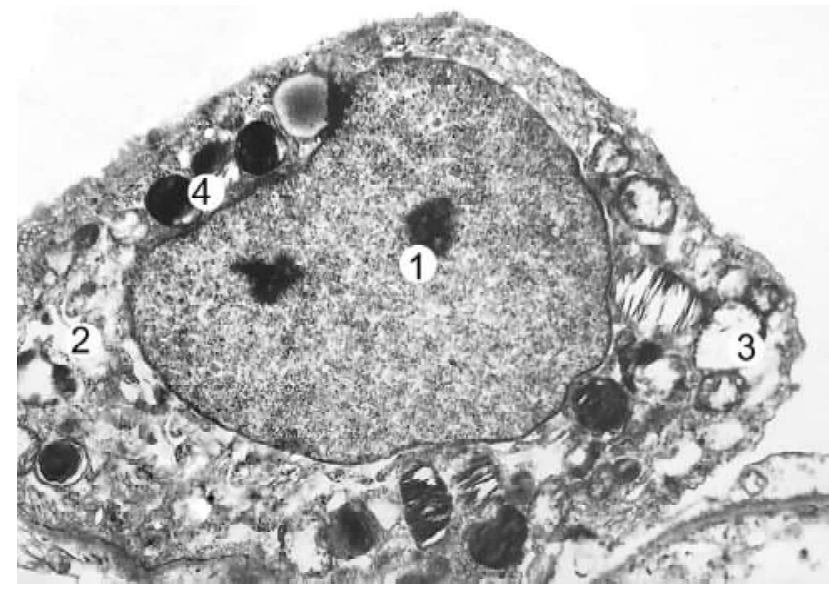

Fig. 3. Ultrastructural state of the secretory alveolocyte of the respiratory department of the lungs a day after thermal trauma. Nuclei with nucleolus (1), dilated tubules of the endoplasmic reticulum (2), emptied lamellar bodies (3), young lamellar bodies (4). $\times 26000$.

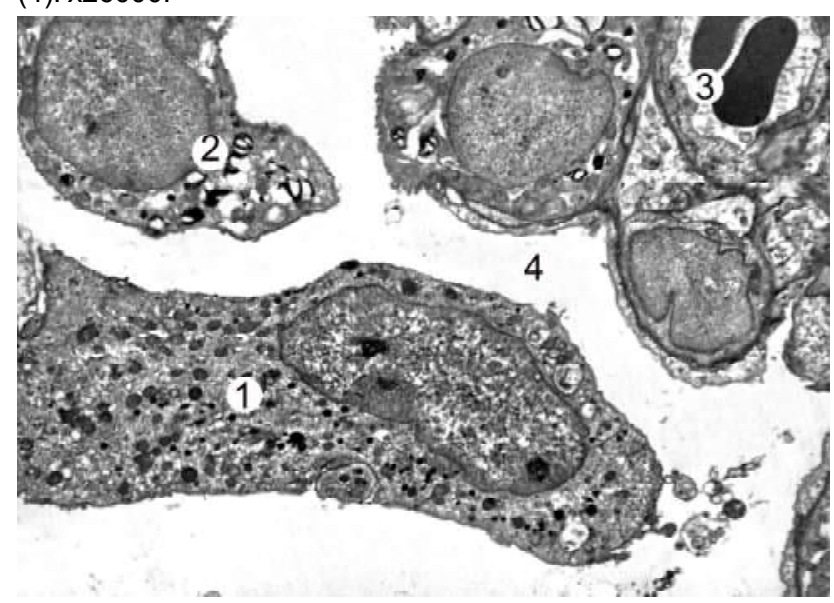

Fig. 4. Ultrastructural condition of alveoli of respiratory department of lungs a day after thermal trauma. Alveolar macrophage (1), type II alveolocytes (2), hemocapillary lumen (3), alveolar lumen (4). x6000.

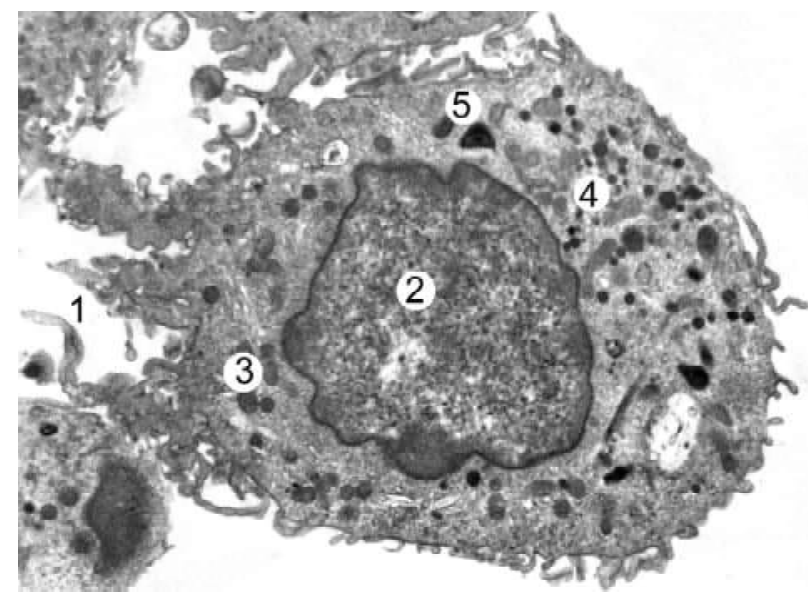

Fig. 5. Ultrastructural state of alveolar macrophage of respiratory department of lungs a day after thermal trauma. Plasmalemma staining (1), nucleus (2), mitochondria (3), primary lysosomes (4), phagosomes (5). x8000. shape, fuzzy contours of the cariole membrane and invaginations. In moderately electron-dense karyoplasm, euchromatin prevails. The cytoplasm of cells is swollen, enlightened, especially in the peripheral regions. The integrity and structural organization of most organelles is partially impaired, with little pinocytosis vesicles. The basement membrane of the aerohematic lung barrier is characterized by swelling, thickening, or some areas of thinning (Fig. 2).

In the stage of burn shock in the secretory alveolocytes rounded nuclei are observed, membranes of the karyolemma are fuzzy, form shallow indentations, in the karyoplasm, euchromatin prevails, nucleolus are found. At some loci, the perinuclear space is enlarged and few nuclear pores are detected. In the cytoplasm of the secretory epitheliocytes, degranulation is observed, which is accompanied by a decrease in the amount of osmiophilic material in the lamellar bodies, and young forms are also present. The tubules of the endoplasmic reticulum are unevenly expanded, with few ribosomes on their membranes. The Golgi complex of type II alveolocytes is represented by expanded cisterns and a small number of vesicles and vacuoles. The mitochondria are hypertrophied, with electron-light matrix and fuzzy crystals. The apical surface of the cells contains few small microvilli (Fig. 3).

In the lumen of the alveoli, there is an increase in the number of alveolar macrophages that are in a state of increased functional activity. A considerable number of cytoplasmic outgrowths are found on their surface. Macrophage nuclei have irregularly shaped and invasive karyolemma. In the karyoplasm prevail euchromatin, there is one or two nuclei. The cytoplasm contains small, osmiophilic primary lysosomes and small secondary lysosomes. Small mitochondria have different shapes and their matrix is electron-dense. Dictyosomes of the Golgi complex are located mainly in the paranuclear space of the cytoplasm and are formed by expanded cisterns, small vesicles and vacuoles. The tubules of the granular endoplasmic reticulum are non-stretchable and thickened, with a moderate number of ribosomes on their membranes (Fig. 4, Fig. 5).

\section{Discussion}

Conducted submicroscopic studies of the components of the alveoli of the lungs in the stage of burn shock in thermal trauma revealed that the pathological link is impaired microcirculation in the walls of the alveoli, and causes the development of local hypoxia and increased proteolysis, permeability of the wall of microvessels with access to the alveoli of plasma components having lipolytic and proteolytic properties, which is fully consistent with scientific works $[7$, 13]. The expressed disturbances of microcirculation in the lungs during burn shock are accompanied by blockage of the capillary bed, stasis, bypass of blood flow, as well as violation of the aerohematic barrier. Interstitial edema creates hypoxia conditions for alveoli cells and, first of all, for large alveolocytes that produce surfactant. 
In the stage of burn shock in the secretory alveolocytes in the cytoplasm there is degranulation, which is accompanied by a decrease in the number of lamellar bodies and osmiophilic material in them. Submicroscopically, there is an increase in the number of alveolar macrophages in the alveolar lumen that are in a state of increased functional activity.

During the period of shock after skin burns, pulmonary edema is detected as a violation of vascular permeability. Significant in this belongs to the segmented leukocytes. Violation of the permeability of microvessels develops as a result of the complex action of a number of factors that are in the blood and released locally by cellular elements during their degradation. The second component of the system of phagocytic cells, together with leukocytes, which are subject to urgent mobilization under conditions of burn shock are alveolar macrophages. Their increase is an adaptation reaction, a manifestation of the tension of all protective systems in a situation critical to the body $[14,17]$.

In the swollen areas of the lung, in the alveoli there is perfusion, but there is no aeration, which contributes to the strengthening of arterial hypoxemia in the period of shock. Thus, pulmonary edema is one of the links in the pathogenesis of burn shock.

However, the lungs are the only organ where not only blood circulation provides the vital function of the organ, but the organ itself exists for the circulation of the main function - gas exchange. Therefore, the unity of the functioning of the

\section{References}

[1] Cherkasov, V. G., Kovalchuk, A. I., Dzevulskaya, I. V., Malikov, A. V., Lakhtadyr, T. V., \& Matkivskaya, R. M. (2015). Structural transformations in the internal organs with infusion therapy for burn disease. Medical science of Ukraine, 11(3-4), 4-11.

[2] Dzevulska, I. V., Kovalchuk, O. I., Cherkasov, E. V., Majewskyi, O. Ye., Shevchuk, Yu. G., Pastukhova, V. A., \& Kyselova, T. M. (2018). Influence of lactoproteinum solution with sorbitol on dna content of cells of endocrine glands on the background of skin burn in rats. World of Medicine and Biology, 2(64), 33-39. doi:10.26724/2079-8334-2018-2-64-33-39

[3] Evers, L. H., Bhavsar, D., \& Mail?nder, P. (2010). The biology of burn injury. Experimental dermatology, 19(9), 777-783. doi: 10.1111/j.1600-0625.2010.01105.x

[4] Gavryluk, A. O., Gunas, I. V., Galunko, G. M., Chereshniuk, I. L., \& Lysenko, D. A. (2017). Indicators of the cell cycle and fragmentation of DNA of cells of small intestinal mucosa through 14,21 and 30 days after burn skin damage on the background of infusion of $0,9 \% \mathrm{NaCl}$ solution. Biomedical and Biosocial Anthropology, 29, 104-108.

[5] Goralskiy, L. P., Homich, V. T., \& Kononskiy, O. I. (2011). Fundamentals of histological technique and morphofunctional methods of research in normal and in pathology. Zhitomir: Polissya.

[6] Gunas, I. V., Guminskiy, Yu. I., Ocheretna, N. P., Lysenko, D. A., Kovalchuk, O. I., Dzevulska, I. V., \& Cherkasov, E. V. (2018). Indicators cell cycle and dna fragmentation of spleen cells in early terms after thermal burns of skin at the background of introduction $0.9 \% \mathrm{NaCl}$ solution. World of Medicine and Biology, 1(63), 116-120. doi: 10.26.724/2079-8334-2018-1-63-116-120

[7] Herold, S., Gabrielli, N. M., \& Vadász, I. (2013). Novel concepts of circulatory and respiratory systems is a necessary, adaptive pattern [13].

Thus, the results obtained from our own studies correlate with the scientific data of other researchers $[13,14,17]$ and allow to conclude that severe thermal trauma in the early term of the experiment leads to disturbances of the ultrastructure of the aerohematical lung barrier. At the stage of shock in the experimental burns, adaptive compensatory changes and the initial signs of destructive ones were established. Hemocapillaries within the alveoli wall have enlarged blood-filled lumps, stasis formation is detected. Swelling of respiratory epitheliocytes and endothelial cells, disturbances in their cytoplasm of organelles, reduction of pinocytosis leads to the deterioration of gas exchange processes in the lungs.

Further studies plan to determine the degree of morphological changes in the structural components of the lung alveoli in dynamics after experimental thermal trauma under the condition of using corrective drugs.

\section{Conclusions}

Severe thermal injury leads to disruption of the ultrastructure of the aerohematic lung barrier. In the stage of shock during the experimental burns, adaptivecompensatory processes and signs of destructive changes of the alveolar epithelium, macrophages and the wall of the hemocapillaries are established, which leads to disruption of gas exchange processes in the lungs.

acute lung injury and alveolar-capillary barrier dysfunction. American Journal of Physiology-Lung Cellular and Molecular Physiology, 305(10), L665-L681. doi: 10.1152/ ajplung.00232.2013

[8] Janak, J. C., Clemens, M. S., Howard, J. T., Le, T. D., Cancio, L. C., Chung, K. K., ... Stewart, I. J. (2018). Using the injury severity score to adjust for comorbid trauma may be double counting burns: implications for burn research. Burns, 44(8), 1920-1929. doi: 10.1016/j.burns.2018.03.012

[9] Jeschke, M. G., Pinto, R., Kraft, R., Nathens, A. B., Finnerty, C. C., Gamelli, R. L., ... Herndon, D. N. (2015). Morbidity and survival probability in burn patients in modern burn care. Critical care medicine, 43(4), 808-815. doi: 10.1097/ CCM. 0000000000000790

[10] Kallinen, O., Maisniemi, K., Bohling, T., Tukiainen, E., \& Koljonen, V. (2012). Multiple organ failure as a cause of death in patients with severe burns. Journal of burn care \& research, 33(2), 206-211. doi: 10.1097/BCR.0b013e3182331e73

[11] Kearney, L., Francis, E. C., \& Clover, A. J. (2018). New technologies in global burn care-a review of recent advances. International journal of burns and trauma, 8(4), 77-87. PMID: 30245912

[12] Maievskyi, O. Y., Bobruk, S. V., \& Gunas, I. V. (2018). Dynamics of histochemical changes in the skin of rats within a month after the burning of II-III degrees on the background of the injection first 7 days HAES-LX-5\% solution. World of Medicine and Biology, 4(66), 180-184. doi: 10.26724/2079-8334-20184-66-180-184

[13] Netyukhailo, L. G., Kharchenko, A. G., \& Kostenko, S. V. (2011). Pathogenesis of burn disease (in 2 parts). World of Medicine 
and Biology, 1, 127-131.

[14] Ocheretnyuk, A. O., Palamarchuk, O. V., Lysenko, D.A., Vashchuk, G. I., \& Stepanyuk, G. I. (2018). Influence of solution of lactoprotein with sorbitol on ultrastructural changes in lungs of rats in the condition of burn shock. Regulatory Mechanisms in Biosystems, 9(3), 440-445. https://doi.org/10.15421/021866

[15] Porter, C., Tompkins, R. G., Finnerty, C. C., Sidossis, L. S., Suman, O. E., \& Herndon, D. N. (2016). The metabolic stress response to burn trauma: current understanding and therapies. The Lancet, 388(10052), 1417-1426. doi: 10.1016/S0140$6736(16) 31469-6$

[16] Rowan, M. P., Cancio, L. C., Elster, E. A., Burmeister, D. M., Rose, L. F., Natesan, S., ... \& Chung, K. K. (2015). Burn wound healing and treatment: review and advancements. Critical care, 19(1),
243. doi: 10.1186/s13054-015-0961-2

[17] Sousse, L. E., Herndon, D. N., Andersen, C. R., Zovath, A., Finnerty, C. C., Mlcak, R. P., ... \& Hawkins, H. K. (2015). Pulmonary histopathologic abnormalities and predictor variables in autopsies of burned pediatric patients. Burns, 41(3), 519527. doi: 10.1016/j.burns.2014.09.014

[18] Tiwari, V. K. (2012). Burn wound: How it differs from other wounds? Indian journal of plastic surgery, 45(02), 364-373. doi: 10.4103/0970-0358.101319

[19] Zhang, D., Chang, Y., Han, S., Yang, L., Hu, Q., Yu, Y., ... \& Chai, J. (2018). The microRNA expression profile in rat lung tissue early after burn injury. Turkish Journal of Trauma and Emergency Surgery, 24(3), 191-198. doi: 10.5505/ tjtes.2018.98123

\section{СУБМІКРОСКОПІЧНІ ЗМІНИ АЛЬВЕОЛ РЕСПІРАТОРНОГО ВІДДІЛУ ЛЕГЕНЬ ЧЕРЕЗ ДОБУ ПІСЛЯ ЕКСПЕРИМЕНТАЛЬНОЇ TEPMІЧНОÏ ТРАВМИ}

Небесна 3.М., Башинська О.І., Очеретна Н.П., Галунко Г.М., Сливка О.Я.

Глибокі, великі за площею термічні опіки не обмежуються тільки місцевими ураженнями тканин, вони викликають значні порушення всіх систем і органів організму, змінюють обмінні процеси. Виявлено, що первинними ланками у патогенезі опікової хвороби є руйнування шкірного покриву, порушення нейроендокринної регуляції та значні гемодинамічні розлади. Реорганізація структур і порушення фонкцій легень, як реакція на патологічний процес в організмі, привертає все більшу увагу науковців. Метою дослідження було встановлення субмікроскопічної перебудови альвеол після термічного ураження на 1 добу після експериментальної термічної травми. Опік III ступеня наносили під кетаміновим наркозом мідними пластинами, нагрітими у киплячій воді до температури 97-100ㄷ. Розміри ділянки ураження складали 18-20 \% епільованої поверхні тіла щурів. Експериментальне вивчення структурних компонентів альвеол легень після опікової травми було виконано на лабораторних білих щурах-самцях масою 160-180 г. Евтаназію щурів проводили після кетамінового наркозу, шляхом декапітації. В експерименті проведено вивчення субмікроскопічного стану стінок альвеол легень після термічної травми. Встановлено, що в стадії шоку після нанесення опікової травми - 1 доба, в альвеолах респіраторного відділу легень виявляються пристосувально-компенсаторні та початкові деструктивні зміни усіх структурних компонентів альвеол. Пошкодження ультраструктури аерогематичного бар'єру проявляється інтрацелюлярним набряком та набряком органел ендотеліоцитів, респіраторних та секреторних епітеліоцитів, в їх деформованих ядрах зростає кількість гетерохроматину. Базальна мембрана також має ознаки набряку, подекуди гомогенна, нечітка. Зменшення числа везикул та мікропіноцитозних пухирців в ендотеліальних та респіраторних епітеліоцитах призводить до порущення ендотеліального та альвеолярного обміну. В альвеолах виявляються чисельні активно фагоцитуючі альвеолярні макрофраги із добре вираженим лізосомальним апаратом. Встановлені початкові альтеративні зміни ультраструктури компонентів аерогематичного бар'єру призводять до порушення газообміну у респіраторному відділі легень.

Ключові слова: альвеоли легень, аерогематичний бар'єр, субмікроскопічні зміни, термічна травма.

\section{СУБМИКРОСКОПИЧЕСКИЕ ИЗМЕНЕНИЯ АЛЬВЕОЛ РЕСПИРАТОРНОГО ОТДЕЛА ЛЕГКИХ ЧЕРЕЗ СУТКИ ПОСЛЕ ЭКСПЕРИМЕНТАЛЬНОЙ ТЕРМИЧЕСКОЙ ТРАВМЫ \\ Небесная 3.М., Башинская Е.И., Очеретная Н.П., Галунко А.М., Сливка О.Я.}

Глубокие, большие по площади термические ожоги не ограничиваются только местными поражениями тканей, они вызывают значительные нарушения всех систем и органов организма, изменяют обменные процессы. Выявлено, что первичными звеньями в патогенезе ожоговой болезни являются разрушение кожного покрова, нарушение нейроэндокринной регуляции и значительные гемодинамические расстройства. Реорганизация структур и нарушение фрункций легких, как реакция на патологический процесс в организме, привлекает все большее внимание ученых. Целью исследования было установление субмикроскопической перестройки альвеол после термического поражения на 1 сутки после экспериментальной термической травмы. Ожог III степени наносили под кетаминовым наркозом медными пластинами, нагретыми в кипящей воде до температуры 97-100 ${ }^{\circ}$ C. Размеры участка поражения составляли 18-20\% эпилированной поверхности тела крыс. Экспериментальное изучение структурных компонентов альвеол легких после ожоговой травмы было выполнено на лабораторных белых крысах-самцах массой 160-180 2. Эвтаназию крыс проводили после кетаминового наркоза путем декапитации. В эксперименте проведено изучение субмикроскопического состояния стенок альвеол легких после термической травмы. Установлено, что в стадии шока после нанесения ожоговой травмы - 1 сутки, в альвеолах респираторного отдела легких определяются приспособительнокомпенсаторные и начальные деструктивные изменения всех структурных компонентов альвеол. Повреждения ультраструктуры аэрогематического барьера проявляется интрацеллюлярным отеком и отеком органелл эндотелиоцитов, респираторных и секреторных эпителиоцитов, в их деформированных ядрах растет количество гетерохроматина. Базальная мембрана также имеет признаки отека, иногда гомогенная, нечеткая. Уменьшение числа везикул и микропиноцитозных пузырьков в эндотелиальных и респираторных эпителиоцитах приводит к нарушению эндотелиального и альвеолярного обмена. В альвеолах определяются многочисленные активно фрагоцитирующие альвеолярные макрофраги с хорошо выраженным лизосомальным аппаратом. Установленные начальные альтеративные изменения ультраструктуры компонентов аэрогематического барьера приводят к нарушению газообмена в респираторном отделе легких.

Ключевые слова: альвеолы легких, аэрогематический барьер, субмикроскопические изменения, термическая травма. 